\title{
Piotr Lis $\mid$ Wspólnie czy indywidualnie? Na własność czy wynajem? Wszystkim czy wybranym? Dylematy współczesnej polskiej polityki mieszkaniowej ${ }^{1}$
}

\section{Together or separately? Owned or rented? Universal or selective? Dilemmas of contemporary Polish housing policy}

The article contains an overview of the housing situation in Poland in three dimensions: the availability of housing, the capacity to buy or rent a dwelling and the quality of housing standards in the context of the national and local housing policies. It begins with an assessment of the scale and dynamics of residential investment in Poland over the last 30 years. In the next part, the author estimates the economic return on housing investments, stressing that expectations as to the growth of housing prices in Poland are the key determinant of investment decisions. As the analysis shows, the promotion of housing ownership has had negative social effects and, with temporarily cheap and available money, has fuelled the growth of housing prices.

\begin{tabular}{r|l}
\hline DOI & https://doi.org/10.31268/StudiaBAS.2021.16 \\
\hline Słowa kluczowe & $\begin{array}{l}\text { rynek mieszkaniowy w Polsce, polityka mieszkaniowa w Polsce, } \\
\text { inwestycje mieszkaniowe w Polsce }\end{array}$ \\
\hline Keywords & $\begin{array}{l}\text { housing market in Poland, housing policy in Poland, housing } \\
\text { investment in Poland }\end{array}$ \\
\hline O autorze & $\begin{array}{l}\text { doktor habilitowany, profesor Uniwersytetu Ekonomicznego } \\
\text { W Poznaniu } ・ \boldsymbol{M} \text { piotr.lis@ue.poznan.pl } \\
\text { ORCID 0000-0001-7942-2668 }\end{array}$ \\
\hline
\end{tabular}

\section{Wstęp}

W opracowaniu podjęto próbę odpowiedzi na trzy pytania badawcze pojawiające się w trakcie studiów nad mieszkalnictwem w Polsce i uznane przez autora za kluczowe w obszarze polityki mieszkaniowej. Pierwsze z nich brzmi: „Wspólnie czy indywidualnie?”, a zatem czy cele główne polityki mieszkaniowej powinny być formułowane przez państwo, a następnie realizowane w programach mieszkaniowych samorządów lokalnych, czy może odwrotnie - ustalanie celów polityki mieszkaniowej powinno być w gestii poszczególnych samorządów lokalnych, a państwo powinno jedynie wspierać lokalne inicjatywy mieszkaniowe. Drugie pytanie: „Na własność czy wynajem?" skłania do zastanowienia się nad tym, czy państwo i samorządy lokalne powinny wspierać budowę mieszkań na własność przyszłych mieszkańców, czy jednak ukierunkować się na tworzenie zasobu mieszkaniowego przeznaczonego na wynajem. Trzecie pytanie: „Wszyst-

1 Projekt finansowany w ramach programu Ministra Nauki i Szkolnictwa Wyższego pod nazwą „Regionalna Inicjatywa Doskonałości" w latach 2019-2022, nr projektu 004/RID/2018/19, kwota finansowania: 3 mln zł. 
kim czy wybranym?" wskazuje kolejny ważny problem - czy państwo i samorządy lokalne powinny realizować politykę mieszkaniową dla możliwie szerokiej grupy beneficjentów, chociaż zakres wsparcia nie będzie znaczny, czy jednak wybór powinien być możliwie wąski, a wsparcie - bardzo intensywne.

Na podstawie pytań badawczych zostały sformułowane trzy tezy. Po pierwsze, prowadzenie polityki mieszkaniowej powinno być zróżnicowane w zależności od potrzeb mieszkaniowych społeczności lokalnych. Po drugie, zrównoważony rozwój mieszkalnictwa wymaga istnienia znaczącego segmentu mieszkań przeznaczonych na wynajem w zasobie mieszkaniowym. Stąd państwo powinno tworzyć ramy instytucjonalne zapewniające rozwój tego segmentu, a samorządy terytorialne powinny realizować projekty będące impulsem do dalszego rozwoju rynku mieszkaniowego. Po trzecie, w polityce mieszkaniowej powinny zostać przyznane wyraźne priorytety w zakresie wsparcia sfery mieszkaniowej przez państwo i władze lokalne. Realizacja kolejnych priorytetów umożliwia bowiem rozszerzenie beneficjentów programów mieszkaniowych o kolejne grupy.

W niniejszym opracowaniu wykorzystano metodę obserwacyjną, metodę badania dokumentów, metodę sondażu diagnostycznego (wybrane wyniki badań kwestionariuszowych przeprowadzonych przez studentów studiów ekonomicznych w Polsce) oraz metodę indywidualnego przypadku dla mieszkania w Warszawie. W pracy posłużono się także materiałem wtórnym, tj. danymi statystycznymi opublikowanymi przez Główny Urząd Statystyczny (GUS), Narodowy Bank Polski i Eurostat. Ponadto wykorzystano opracowania trzech zespołów badawczych opublikowane przez fundację Warszawski Instytut Bankowości, tj.: P. Jareckiego, E. Kucharskiej-Stasiak, A. Miklaszewskiej, K. Olbińskiej, B. Wieteski-Rosiak, M. Załęcznej Optymalne programy wsparcia budownictwa mieszkaniowego - analiza efektywności, M. Bryxa i I. Rudzkiej Alternatywny model kredytowania hipotecznego na cele mieszkaniowe, a także M. Bryxa, I. Rudzkiej i S. Łobejki Dostępność mieszkań na własność i wynajem w Polsce - I półrocze 2020 r.

Na podstawie trzech pytań badawczych i postawionych tez przyjęto następujący układ opracowania. Na wstępie zdefiniowano, czym jest polityka mieszkaniowa w węższym i szerszym zakresie. Determinantem wyznaczania celów polityki mieszkaniowej są potrzeby mieszkaniowe. Stąd na kolejnym etapie dokonano próby charakterystyki sytuacji mieszkaniowej Polek i Polaków w wymiarze ilościowym (dostępności mieszkań), jakościowym i cenowym (zdolności do nabycia/najmu mieszkania). Wnioski z tej analizy posłużyły do dyskusji i sformułowania rekomendacji dla polityki mieszkaniowej.

\section{Czym jest polityka mieszkaniowa?}

Polityka mieszkaniowa jest jedną z polityk sektorowych prowadzonych zarówno na szczeblu centralnym przez rząd, jak i na szczeblu lokalnym przez gminy. Angażuje podmioty publiczne, organizacje polityczne i społeczne oraz podmioty prywatne do osiągnięcia w obszarze mieszkalnictwa celów głównych, długookresowych, jakimi są: a) tworzenie warunków do zakupu lub najmu mieszkań przez wszystkich obywateli, b) zapewnienie dostępności zasobu mieszkaniowego, tj. realizowanie odpowiedniej skali inwestycji mieszkaniowych z wykorzystaniem 
przede wszystkim mechanizmu rynkowego, c) wspieranie odpowiedniej jakości zasobu mieszkaniowego w całym okresie użytkowania nieruchomości². Polityka mieszkaniowa jest również rozumiana, w szerszym ujęciu, jako główne kierunki i metody działania państwa i innych instytucji publicznych oraz organizacji politycznych i społecznych, mające wpływ na mieszkalnictwo i zaspokojenie potrzeb mieszkaniowych ${ }^{3}$. Z perspektywy makro polityka mieszkaniowa okazuje się częściowo zbieżna z polityką społeczną, gdyż społeczny obszar mieszkalnictwa jest jednym z filarów polityki społecznej, i częściowo zbieżna z polityką gospodarczą w zakresie funkcjonowania rynków mieszkaniowych, finansowych i kapitałowych. Z perspektywy mezo i mikro polityka mieszkaniowa jest elementem polityk miejskich ${ }^{4}$.

\section{Charakterystyka sytuacji mieszkaniowej Polek i Polaków}

Ocena potrzeb mieszkaniowych z perspektywy polityki mieszkaniowej, która stanowi podstawę do wyznaczania celów tej polityki, jest dokonywana z zewnątrz, w sposób zagregowany, a nie z perspektywy poszczególnych, indywidualnych gospodarstw domowych. W konsekwencji może powstać rozdźwięk pomiędzy oczekiwaniami indywidualnych gospodarstw domowych (determinowanymi przez aspiracje, obecny i pożądany status społeczny) a potrzebami mieszkaniowymi społeczeństwa zidentyfikowanymi w skali lokalnej, regionalnej, krajowej czy międzynarodowej ${ }^{5}$.

W niniejszym opracowaniu scharakteryzowano sytuację mieszkaniową w Polsce, w której przenikały się kwestie potrzeb i oczekiwań mieszkaniowych. Sytuacja mieszkaniowa została przedstawiona w trzech wymiarach: 1) ilościowym, skoncentrowanym na inwestycjach mieszkaniowych i zmianie liczebnej zasobu mieszkaniowego, 2) jakościowym, dotyczącym przede wszystkim zmian w standardzie mieszkaniowym, 3) cenowym, skoncentrowanym na problemie zmian zdolności do nabycia czy najmu mieszkań przez gospodarstwa domowe.

\section{Wymiar ilościowy sytuacji mieszkaniowej}

W Polsce w latach 1991-2020 liczba mieszkań rosła o średnio 129 tys. lokali rocznie (mediana 133 tys.), przy czym po zmianach ustrojowych (wykres 1) wzrost ten był w Polsce rekordowy w latach 2016-2020. Tylko w tych pięciu latach przybyło prawie 1 mln mieszkań, co stanowiło ponad 6\% zasobu mieszkaniowego (według stanu na 31 grudnia 2019 r.). Dla porównania cał-

2 P. Lis, Polityka państwa w zakresie finansowania inwestycji mieszkaniowych, C.H. Beck, Warszawa 2008.

3 A. Andrzejewski, Polityka mieszkaniowa, wyd. 3 zmien., Państwowe Wydawnictwo Ekonomiczne, Warszawa 1987; P. Lis, Cele i instrumenty społecznej polityki mieszkaniowej [W:] Współczesne przemiany środowiska mieszkaniowego - wybrane problemy, red. J. Dzieciuchowicz, Wydawnictwo Uniwersytetu Łódzkiego, Łódź 2011, s. 9-28; A. Zubrzycka-Czarnecka, Social Actors in the Housing Policy Process. A Constructivist Perspective, Elipsa, Warszawa 2019.

4 P. Lis, Polityka mieszkaniowa dla Polski. Dlaczego potrzeba więcej mieszkań na wynajem i czy powinno je budować państwo?, Forum Idei, Fundacja im. Stefana Batorego, Warszawa 2019. Por. także: A. Zubrzycka-Czarnecka, Polityka mieszkaniowa we Francji na przełomie XX i XXI wieku, Aspra, Warszawa 2011; eadem, Polityka miejska wobec starzenia się populacji miast - na przykładzie Polski, Francji i Kanady, „Problemy Polityki Społecznej. Studia i Dyskusje" 2012, nr 18, s. 119-128.

5 P. Lis, Polityka mieszkaniowa..., s. 3. 
kowity zasób mieszkaniowy Warszawy wynosił 997 tys. mieszkań na koniec 2019 r. ${ }^{6}$ Oznacza to, że w ciągu ostatnich pięciu lat w Polsce powstała niemal „kolejna Warszawa” nowych mieszkań. Skala inwestycji w nieruchomości mieszkaniowe prowadzonych w Polsce była więc bardzo duża, przy czym były one przeprowadzane przy dynamicznym wzroście cen mieszkań.

\section{Wykres 1. Mieszkania oddane do użytku w Polsce w latach 1991-2020}

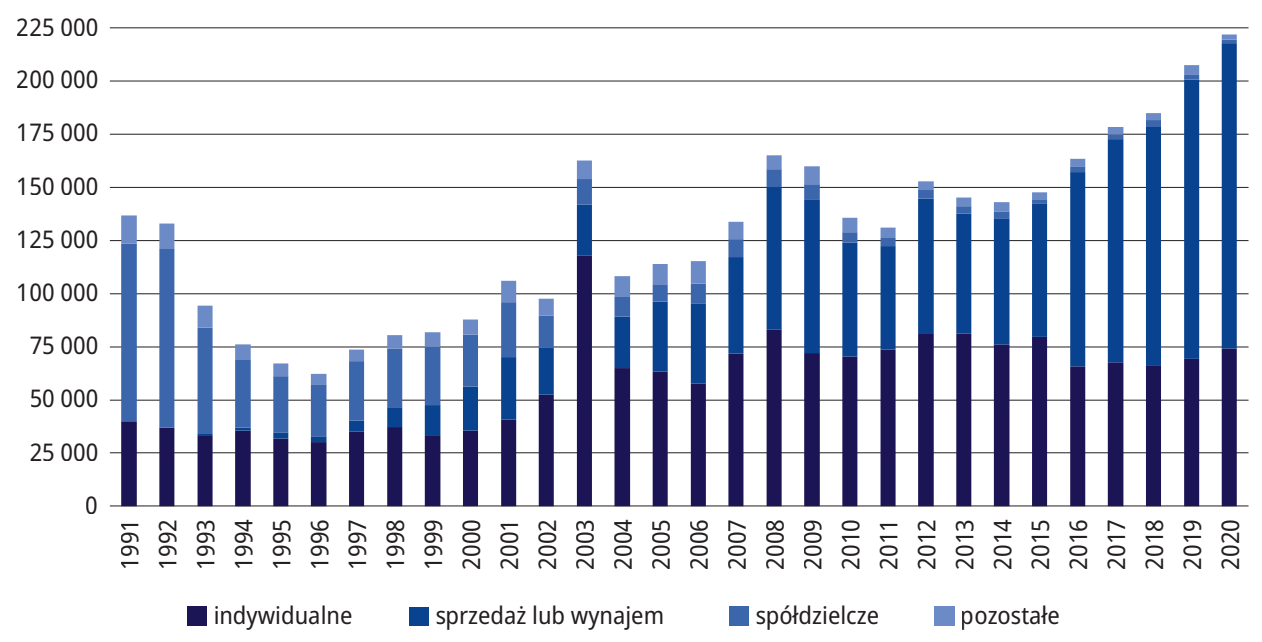

Źródło: opracowanie na podstawie danych GUS, różne lata.

W strukturze inwestycji mieszkaniowych w Polsce w latach 1991-2020 dominowało budownictwo mieszkaniowe realizowane przez deweloperów i indywidualne w systemie gospodarczym. Realizacja inwestycji mieszkaniowych w takich formach była skoncentrowana niemal wyłącznie na budowie mieszkań na własność, tj. nieruchomości lokalowych i nieruchomości zabudowanych budynkiem mieszkaniowym jednorodzinnym.

Na wykresie 2 zostały zestawione transakcje kupna-sprzedaży nieruchomości w Polsce w latach 2004-2019 na podstawie danych z rejestrów cen zebranych przez Główny Urząd Statystyczny ${ }^{7}$. W odniesieniu do nieruchomości lokalowych wystąpił niespotykany wcześniej boom mieszkaniowy w latach 2015-2019. Tylko w tym okresie sprzedano 948 tys. nieruchomości lokalowych ${ }^{8}$. Rekordy w liczbie transakcji kupna-sprzedaży nieruchomości zanotowano w 2019 r. zarówno dla nieruchomości lokalowych, jak i dla nieruchomości gruntowych niezabudowanych i nieruchomości gruntowych zabudowanych ${ }^{9}$.

6 Główny Urząd Statystyczny, Rocznik Statystyczny Warszawy 2020, Warszawa 2020, s. 150.

7 Główny Urząd Statystyczny, Obrót nieruchomościami w 2019 r., Warszawa 2020. Por. także opracowania za wcześniejsze lata.

8 Obliczenia własne na podstawie publikacji GUS, Obrót nieruchomościami w 2014 r. Por. także opracowania dla kolejnych lat - do 2019 r.

9 Główny Urząd Statystyczny, Obrót nieruchomościami w 2019 r., Warszawa 2020. 
Wykres 2. Liczba transakcji kupna-sprzedaży nieruchomości w Polsce w latach 2004-2019

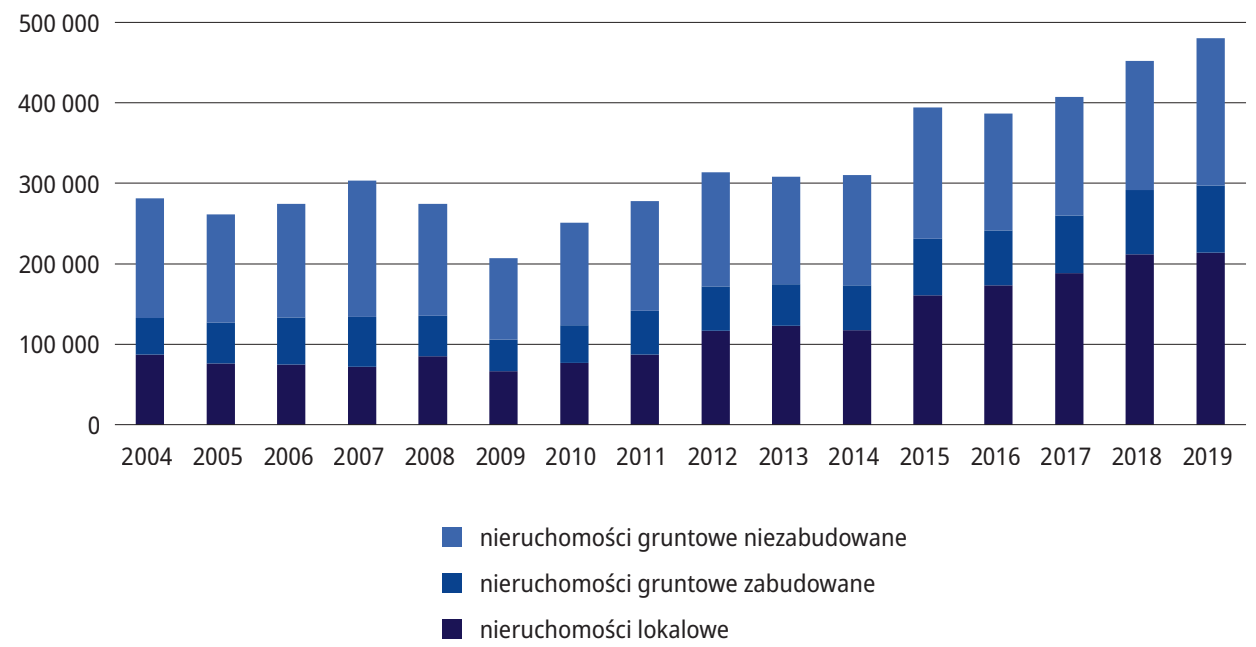

Źródło: opracowanie własne na podstawie danych Głównego Urzędu Statystycznego, Obrót nieruchomościami w 2019 r., Warszawa 2020 i publikacji za lata wcześniejsze.

Gdy uwzględni się ogromny popyt na nieruchomości w Polsce przy rekordowej podaży nieruchomości, w szczególności mieszkaniowych, rodzi się pytanie o przyczyny i konsekwencje tej sytuacji. Jednym z podstawowych powodów jest aktywność inwestorów na rynkach mieszkaniowych, którzy traktują mieszkania jako aktywa w swoich portfelach inwestycyjnych. Osoby szukające zysku na rynku nieruchomości kierują się niezwykle silnymi oczekiwaniami (o charakterze adaptacyjnym) dalszego wzrostu cen nieruchomości w Polsce, tak jak to było w ostatniej dekadzie. Dopóki się one spełniają, czyli ceny mieszkań rosną, dopóty inwestycje tego rodzaju są opłacalne. Nieruchomości jawią się jako atrakcyjne aktywa, dzięki którym można zachować wartość pieniądza w czasie w obliczu niskich stóp procentowych. Oczywiście tylko dla osób, które miały zgromadzone oszczędności, a ich wynagrodzenie pozwalało na otrzymanie kredytu hipotecznego.

W tym miejscu jest zasadne zobrazowanie przykładem stwierdzenia, że na rynku nieruchomości mieszkaniowych w Polsce decydujące znaczenie mają oczekiwania dotyczące wzrostu cen mieszkań w kolejnych latach. Oczywiście autor ma świadomość ograniczeń analizy jednego, chociaż znaczącego, lokalnego rynku mieszkaniowego. Przykład opiera się na danych o stawkach czynszów, cenach transakcyjnych i oprocentowaniu 10-letnich obligacji Skarbu Państwa przyjętych w opracowaniu Narodowego Banku Polskiego ${ }^{10}$. Przedmiotem analizy jest nieruchomość lokalowa położona w Warszawie o powierzchni użytkowej $50 \mathrm{~m}^{2}$. W niniejszym

10 Narodowy Bank Polski, Raport o sytuacji na rynku nieruchomości mieszkaniowych i komercyjnych w Polsce w 2019 r., Departament Stabilności Finansowej NBP, Warszawa 2020, s. 90-91. 
opracowaniu założono dwa scenariusze: a) kapitał na zakup mieszkania w 100\% pochodził od nabywcy, b) kapitał na zakup mieszkania w połowie pochodził od nabywcy, w połowie z kredytu hipotecznego. Stopa zwrotu z zainwestowanego kapitału stanowiła relację wyniku netto do kapitału własnego. Na warszawskim rynku nieruchomości według założeń wskaźnik pustostanów wynosi $13 \%$, 1\% to zaległości czynszowe, 20\% - wydatki operacyjne, a zryczałtowany podatek płacony z góry od całego dochodu związanego z wynajmem mieszkania określono na 8,5\%. Przyjęto, że alternatywnym kosztem kapitału będzie zakup 10-letnich obligacji Skarbu Państwa. Będzie to zatem inwestycja o zdecydowanie niższym ryzyku niż inwestycja mieszkaniowa. Oszacowano spread, czyli różnicę pomiędzy stopą zwrotu z kapitału własnego a oprocentowaniem alternatywnego kosztu kapitału. W scenariuszu z finansowaniem połowy zakupu mieszkania z kredytu hipotecznego przyjęto, że jego oprocentowanie wyniesie $2,45 \%$, raty będą miesięczne, w niezmiennej wysokości. Z szacunków wynika jednoznacznie, że inwestycja mieszkaniowa nie generowała oczekiwanego zysku ekonomicznego w latach 2014-2019 (tabela 1). Różnica pomiędzy stopą zwrotu z zainwestowanego kapitału była wyższa od oprocentowania obligacji Skarbu Państwa o 0,9-2,6\%, co nie odzwierciedla wyższego ryzyka inwestycji w nieruchomości mieszkaniowe w stosunku do inwestycji w obligacje Skarbu Państwa. W wariancie z kredytem hipotecznym spread jest niższy niż bez kredytu hipotecznego, co wynika z braku możliwości skorzystania z dźwigni finansowej w przypadku nabywania mieszkań przez osoby fizyczne nieprowadzące działalności gospodarczej. Przyjęcie alternatywnego kosztu kapitału dla inwestycji o porównywalnym ryzyku z ryzykiem, które wiąże się z inwestycją w nieruchomości mieszkaniowe, spowodowałoby ujemny spread, a w konsekwencji - straty ekonomiczne i spadek wartości inwestycji. Stąd tylko wzrost cen mieszkań sprawia, że pojawiają się istotne korzyści po stronie inwestora, który wcześniej zakupił nieruchomość mieszkaniową po niższej cenie.

Tabela 1. Zysk ekonomiczny z inwestycji w nieruchomości mieszkaniowe w latach 2014-2019

\begin{tabular}{|c|c|c|c|c|c|c|c|c|c|}
\hline$\frac{y}{y}$ & 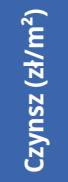 & 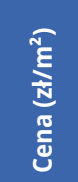 & 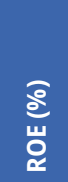 & 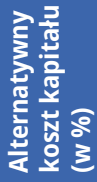 & 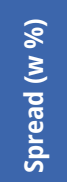 & 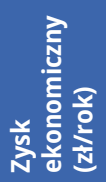 & 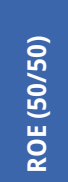 & 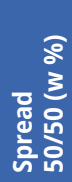 & 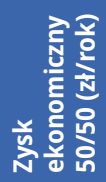 \\
\hline 2014 & 43,6 & 7601 & $4,2 \%$ & $2,6 \%$ & $1,6 \%$ & 6233 & $3,1 \%$ & $1,5 \%$ & 1001 \\
\hline 2015 & 45,0 & 7682 & $4,3 \%$ & $2,8 \%$ & $1,5 \%$ & 5938 & $3,3 \%$ & $1,8 \%$ & 1035 \\
\hline 2016 & 48,4 & 7871 & $4,6 \%$ & $3,3 \%$ & $1,3 \%$ & 5112 & $3,8 \%$ & $2,5 \%$ & 1072 \\
\hline 2017 & 49,7 & 8202 & $4,5 \%$ & $3,4 \%$ & $1,1 \%$ & 4693 & $3,7 \%$ & $2,6 \%$ & 687 \\
\hline 2018 & 52,2 & 9013 & $4,4 \%$ & $3,1 \%$ & $1,3 \%$ & 5700 & $3,4 \%$ & $2,1 \%$ & 623 \\
\hline 2019 & 55,2 & 9857 & $4,2 \%$ & $2,0 \%$ & $2,2 \%$ & 11053 & $3,1 \%$ & $0,9 \%$ & 2790 \\
\hline
\end{tabular}

Źródło: opracowanie i obliczenia własne z wykorzystaniem danych Narodowego Banku Polskiego (2020) dla stawek czynszów, cen i oprocentowania obligacji Skarbu Państwa (kolumna 5). 
Gdy odniesiemy się do boomu mieszkaniowego z lat 2015-2020, powstaje pytanie o wykluczonych z rynku mieszkaniowego. Specjaliści ds. polityki mieszkaniowej M. Bryx i I. Rudzka ${ }^{11}$ wskazują, że istniejący system finansowania inwestycji mieszkaniowych tworzy bariery utrudniające nabycie mieszkań przez osoby młode w wieku 26-35 lat, przede wszystkim w zakresie wkładu własnego koniecznego do nabycia mieszkania (połowa respondentów odpowiedziała, że nie ma środków finansowych na wkład własny). Warto podkreślić, że z tych samych badań wynika, iż jedna trzecia osób młodych nie chce być obciążona kredytem przez całe życie ${ }^{12}$.

Z kolei w badaniach zespołu badawczego autora niniejszego opracowania, przeprowadzonych w listopadzie 2020 r. i w maju 2021 r. wśród studentów kierunków ekonomicznych (w pierwszym przypadku w Poznaniu, w drugim przypadku w całej Polsce), osoby młode w wieku 18-25 lat deklarowały w niemal identycznej skali, tj. w 80\%, że będą dążyć do zakupu własnego mieszkania albo domu jednorodzinnego lub budowy własnego domu jednorodzinnego do 2030 r. Co ciekawe, identyczna część osób młodych w obu badaniach, tj. 42\%, preferowała własność niezależnie od wszelkich zachęt związanych z najmem ${ }^{13}$.

W konsekwencji inwestycji mieszkaniowych na wielką skalę zasób mieszkaniowy w Polsce według danych GUS wzrósł z 14,1 mln mieszkań w 2015 r. do 14,8 mln mieszkań w 2019 r. ${ }^{14}$ Dominowały miasta, gdzie było zlokalizowanych prawie $68 \%$ lokali mieszkalnych. Tylko pięć miast: Warszawa, Kraków, Łódź, Wrocław i Poznań skupiało prawie jedną czwartą wszystkich zasobów miejskich ${ }^{15}$. Różnicę pomiędzy wzrostem liczby mieszkań w zasobie mieszkaniowym a liczbą nowych mieszkań oddanych do użytkowania można jedynie częściowo uzasadnić rozbiórkami zasobu mieszkaniowego będącego w awaryjnym stanie technicznym. Dane kolejnego spisu powszechnego powinny dostarczyć niezbędnych informacji, które pozwolą wyjaśnić tę lukę.

W obszarze statystyki publicznej pojawia się jeszcze jeden problem istotny dla rozważań nad niezaspokojonymi potrzebami mieszkaniowymi. Według danych GUS w latach 2015-2020 nie wystąpiły zasadnicze zmiany w liczbie populacji Polski, która wynosi 38,3 mln osób ${ }^{16}$. Należy jednak podkreślić, że bilans ludności sporządzony przez GUS opiera się na wynikach Narodowego Spisu Powszechnego Ludności i Mieszkań z dnia 31 marca 2011 r. oraz nie obejmuje osób przybyłych z zagranicy na pobyt czasowy (bez względu na okres ich czasowego przebywania), natomiast ujmuje stałych mieszkańców Polski przebywających czasowo za granicą (bez względu na okres ich nieobecności) ${ }^{17}$. Z opracowania GUS dotyczącego migracji wynika, że poza

11 M. Bryx, I. Rudzka, Alternatywny model kredytowania hipotecznego na cele mieszkaniowe, Warszawski Instytut Bankowości, Warszawa 2020.

12 Ibidem, s. 48-49.

13 P. Lis, Z. Rataj, K. Suszyńska, Limitations in the Diffusion of Collaborative Housing. Evidence from Poland (praca nieopublikowana).

14 Główny Urząd Statystyczny, Gospodarka mieszkaniowa i infrastruktura komunalna w 2019 r., Warszawa 2020, s. 15 oraz Główny Urząd Statystyczny, Gospodarka mieszkaniowa w latach 2013-2017, Warszawa-Lublin 2018, S. 14.

15 Główny Urząd Statystyczny, Gospodarka mieszkaniowa w latach..., s. 56.

16 Główny Urząd Statystyczny, Ludność. Stan i struktura oraz ruch naturalny w przekroju terytorialnym w 2020 r. (stan w dniu 3 XII), Warszawa 2021, s. 14.

17 Ibidem, s. 32-33. 


\title{
Wykres 3. Udział mieszkań na własność w zasobie ogółem w państwach Unii Europejskiej* w latach 2015 i 2019
}

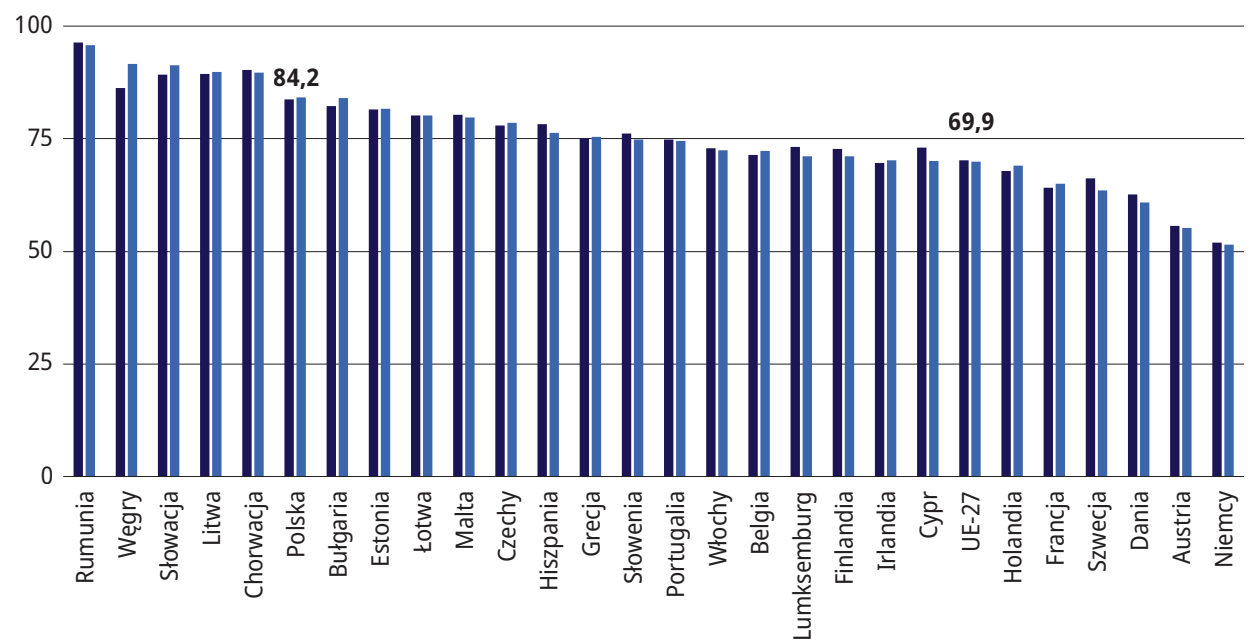

$2015 \square 2019$

\begin{abstract}
* Dane dla Słowacji, Litwy, Hiszpanii, Portugalii, Włoch, Belgii, Luksemburga, Irlandii, Cypru, średniej UE-27 (z wyłączeniem Wielkiej Brytanii), Szwecji i Niemiec za 2018 r.

Źródło: Eurostat, Distribution of Population by Tenure Status, Type of Household and Income Group - EU-SILC survey (ilc_lvho02).
\end{abstract}

granicami Polski przebywało czasowo 2,4 mln stałych mieszkańców naszego kraju na koniec 2019 r. (w szczególności w Niemczech, Wielkiej Brytanii, Holandii i Irlandii) ${ }^{18}$. Znaczna część spośród nich jest zatem ujmowana w bilansie ludności, ale faktycznie zamieszkuje poza Polską i jedynie widnieje w rejestrze osób zameldowanych w kraju. Statystyka publiczna nie dostarcza niezbędnych danych, by móc odpowiedzieć na pytanie, ile osób faktycznie w Polsce mieszka. W konsekwencji opieranie się w obszarze mieszkalnictwa na wskaźnikach, w których ludność Polski jest utożsamiana z liczbą mieszkańców faktycznie zamieszkałych w Polsce, prowadzi do licznych błędów interpretacyjnych. Zdaniem autora nie można stosować danych o wynikach sektora mieszkaniowego w odniesieniu do liczby ludności w Polsce bez zastosowania korekty sprowadzającej dane populacyjne do liczby osób faktycznie mieszkających w kraju. Mierniki mieszkaniowe na 1000 ludności czy szacunki różnic pomiędzy zasobem mieszkaniowym a liczbą gospodarstw domowych są obarczone poważnym błędem.

W strukturze zasobu mieszkaniowego dominowała własność osób fizycznych, która w 2018 r. wynosiła 79\% ogółu lokali mieszkalnych. Ważnym właścicielem zasobu, ale już nie inwestorem, pozostają spółdzielnie mieszkaniowe, które posiadają 14\% mieszkań w Polsce, oraz gminy jako

18 Główny Urząd Statystyczny, Sytuacja demograficzna Polski do 2019 r. Migracje zagraniczne ludności w latach 2000-2019, Warszawa 2020, s. 97. 
właściciel 6\% mieszkań. Marginalny jest udział towarzystw budownictwa społecznego - tylko 0,7\%. W Polsce dominuje własność mieszkań nad mieszkaniami przeznaczonymi na wynajem $84 \%$ do $16 \%$ w zasobie mieszkaniowym ogółem (wykres 3). Polska znajduje się wśród kilku państw, w których własność zasobu mieszkaniowego jest dominująca. Do tej grupy należą: Rumunia, Węgry, Słowacja, Litwa, Chorwacja, Bułgaria, Estonia i Łotwa (ponad 80\% mieszkań własnościowych w strukturze zasobu). Warto zauważyć, że nie ma wśród nich żadnego państwa z Europy Zachodniej, które w sferze mieszkaniowej bardzo dbają o jej zrównoważony rozwój, a więc odpowiedni stosunek lokali własnościowych i mieszkań na wynajem. W Polsce właściciele mieszkań w większości zasiedlają niezadłużony zasób, ale dotyczy to przede wszystkim osób, które posiadały mieszkania już przed 1989 r. Tylko 11\% właścicieli zasobu mieszkaniowego ma zobowiązania w postaci kredytu hipotecznego.

W 2019 r. na najem lokali z mieszkaniowego zasobu gmin, z wyłączeniem lokali zamiennych i tymczasowych pomieszczeń, oczekiwało 151 tys. gospodarstw domowych, głównie w miastach (86\% gospodarstw domowych). Ponad 81 tys. gospodarstw domowych liczyło na najem socjalny lokali z mieszkaniowego zasobu gmin, z tego 48 tys. gospodarstw oczekiwało na najem w ramach realizacji wyroków eksmisyjnych. Jeśli chodzi o zasoby tymczasowych pomieszczeń gmin, to liczba oczekujących wynosiła 18 tys. ${ }^{19}$ Dane te odzwierciedlają skalę potrzeb mieszkaniowych w segmencie mieszkań komunalnych i socjalnych.

\section{Wymiar jakościowy sytuacji mieszkaniowej}

Sytuacja mieszkaniowa w Polsce pod względem standardu mieszkaniowego systematycznie się poprawia. Średni metraż mieszkania w Polsce to prawie $75 \mathrm{~m}^{2}$, przy czym mieszkania na wsi były o prawie $30 \mathrm{~m}^{2}$ większe niż w mieście. Przeciętna liczba izb przypadająca na mieszkanie wyniosła 3,82, w tym w miastach - 3,56, a na obszarach wiejskich - 4,37. Gdy weźmie się pod uwagę ograniczenia statystyki publicznej w zakresie liczby ludności faktycznie zamieszkałej w Polsce, formalnie na jedno mieszkanie przypadało przeciętnie 2,6 osoby ${ }^{20}$.

W odniesieniu do wyposażenia mieszkań w infrastrukturę techniczną należy podkreślić, że instalacja gazowa znajdowała się w co drugim mieszkaniu, do sieci wodociągowej było podłączone 97\% mieszkań, w ustęp było wyposażone 94\% lokali, a w łazienkę - 92\%. Sytuacja ta poprawia się z roku na rok, ale wciąż w drugiej dekadzie XXI w. co 12. mieszkanie nie ma tak podstawowej infrastruktury, jak łazienka czy ubikacja ${ }^{21}$.

W kontekście jakości mieszkalnictwa w Polsce warto zwrócić uwagę na jeden z mierników ubóstwa energetycznego, czyli niezdolność do utrzymania ciepła w mieszkaniach. Przeciętnie 6,9\% ludności w państwach UE-27 (z wyłączeniem Wielkiej Brytanii) w 2019 r. nie mogło zapewnić wystarczającego ciepła w swoim miejscu zamieszkania. W Polsce ten wskaźnik wyniósł 4,2\% w 2019 r. i systematycznie spada, co stanowi bardzo dobry wynik na tle takich państw, jak Niemcy czy Francja. Niemniej w tym obszarze dostrzega się istotne zagrożenia w kolejnych la-

19 Główny Urząd Statystyczny, Gospodarka mieszkaniowa..., s. 19.

20 Ibidem, s. 11-14.

21 Ibidem, s. 16. 
tach, wynikające ze wzrostu cen energii elektrycznej i paliw stałych związanego z koniecznością poniesienia znaczących kosztów inwestycji w sektorze energetyki.

\section{Wymiar cenowy sytuacji mieszkaniowej}

Z perspektywy cenowej lokalne rynki nieruchomości rozwijają się w Polsce bardzo dynamicznie: ceny mieszkań rosły w latach 2016-2020, przy delikatnej korekcie dynamiki wzrostu od II kwartału 2020 r. $^{22}$

Zdolność do nabycia mieszkania na własność można badać z wykorzystaniem wskaźnika dostępności mieszkania. Jest to miara potencjalnej możliwości zakupu powierzchni mieszkania w cenie transakcyjnej za przeciętne miesięczne wynagrodzenie w sektorze przedsiębiorstw w danym mieście. Wyraża ona liczbę $\mathrm{m}^{2}$ mieszkania możliwych do nabycia przy przeciętnym wynagrodzeniu i przeciętnej cenie transakcyjnej. Wskaźnik szacowanej dostępności mieszkań w dużych miastach (opierający się na przeciętnym miesięcznym wynagrodzeniu w sektorze przedsiębiorstw) wyniósł średnio 0,76 $\mathrm{m}^{2}$ w III kwartale $2020 \mathrm{r}^{23}$ Należy podkreślić, że w Polsce zdolność gospodarstw domowych do nabywania mieszkań się zmniejsza, mimo wzrostu wynagrodzeń.

Przy badaniu zdolności do nabycia mieszkania na własność z wykorzystaniem kredytu hipotecznego można posłużyć się wskaźnikiem kredytowej dostępności mieszkania. Jest to miara określająca liczbę $\mathrm{m}^{2}$ mieszkania, które można zakupić ze środków pochodzących z kredytu hipotecznego przy przeciętnym miesięcznym wynagrodzeniu w sektorze przedsiębiorstw na danym rynku, z uwzględnieniem wymogów kredytowych banku i parametrów kredytu, przy średniej cenie transakcyjnej mieszkania. Kredytowa dostępność mieszkania spada w Polsce od 2017 r., z lekkim odbiciem w I kwartale 2020 r. Należy przy tym podkreślić, że wciąż znaczna część mieszkań jest nabywana za środki własne (72-procentowy udział środków własnych w zakupie mieszkań na rynku pierwotnym w siedmiu miastach Polski ${ }^{24}$ ).

\section{Wspólnie czy indywidualnie?}

Na podstawie przedstawionej charakterystyki sytuacji mieszkaniowej w Polsce w długim okresie można podjąć próbę odpowiedzi na pierwsze pytanie: „Wspólnie czy indywidualnie?”. A zatem w jaki sposób rząd i władze lokalne powinny wyznaczać cele i tworzyć programy mieszkaniowe: wspólnie czy indywidualnie? Jak rząd i władze lokalne powinny wspierać mieszkańców w zaspokojeniu potrzeb mieszkaniowych: wspólnie czy indywidualnie?

Rolą rządu powinno być przede wszystkim tworzenie regulacji i ram instytucjonalnych umożliwiających rozwój nowych form zamieszkania zaspokajających potrzeby współczesne-

22 Eurostat, House price index - quarterly date [PRC_HPI_Q], https://appsso.eurostat.ec.europa.eu/nui/show. do?dataset=prc_hpi_q\&lang=en [dostęp: 11 czerwca 2021 r.].

23 Narodowy Bank Polski, Informacja o cenach mieszkań i sytuacji na rynku nieruchomości mieszkaniowych i komercyjnych w Polsce w III kwartale 2020 r., Warszawa 2020, s. 2.

24 Narodowy Bank Polski, Informacja o cenach mieszkań i sytuacji na rynku nieruchomości mieszkaniowych i komercyjnych w Polsce w II kwartale 2020 r., Warszawa 2020, s. 16. 
go społeczeństwa, wsparcie ładu przestrzennego i stabilnego systemu finansowania inwestycji mieszkaniowych, w tym wypracowanie rozwiązań w zakresie finansowania pierwszego mieszkania z kredytu mieszkaniowego przez młode osoby. Polityka mieszkaniowa powinna wkomponowywać się w mechanizmy rynkowe, nie może ich zaś wypierać, w żadnym wypadku nie powinna ich zastępować. Zadaniem rządu powinno być nadanie kierunku rozwojowi sfery mieszkaniowej z uwzględnieniem trzech ważnych obszarów: polityki klimatycznej, wartości wspólnej i równości obywatelskiej. Z przedstawionej wcześniej charakterystyki sytuacji mieszkaniowej wynika, że etap rozwoju ilościowego w polityce mieszkaniowej powinien zostać zastąpiony pobudzeniem przemian w zakresie jakości zasobu mieszkaniowego. Współcześnie kwestie te zostały uwzględnione jedynie w nielicznych przedsięwzięciach realizowanych lokalnie. Dobrym przykładem jest utworzenie Warszawskiego Standardu Mieszkaniowego czy realizacja projektu Nowe Żerniki we Wrocławiu. Inicjatywy te zakładają udział aktorów społecznych (interesariuszy) w procesie tworzenia i realizacji polityki mieszkaniowej, co jest jedną z kluczowych cech mieszkalnictwa w XXI w. ${ }^{25} \mathrm{~W}$ polityce mieszkaniowej główną rolę wciąż odgrywa ilościowe podejście do mieszkalnictwa. Cel wyrażony w haśle „Buduj” powinien jednak być zastępowany celem zobrazowanym hasłem „Zmieniaj”. Zmieniaj swój kwartał, swoje osiedle, swoją dzielnicę, zmieniaj (w sensie: poprawiaj) swoje sąsiedztwo, otoczenie, swoją infrastrukturę techniczną i społeczną, zmieniaj podejście do budowy i mieszkania w kierunku postawy kooperatywnej, zmieniaj swój sposób ogrzewania mieszkania na niskoemisyjny.

Kluczowe różnice w wyznaczaniu celów i w doborze instrumentów będą widoczne pomiędzy średnimi, dużymi miastami i metropoliami a małymi miejscowościami i obszarami wiejskimi. Stąd największą wiedzę o potrzebach mieszkaniowych posiadają władze lokalne. Rozdźwięk we wnioskach z diagnozy sytuacji mieszkaniowej, ale także utrwalony sposób postrzegania mieszkalnictwa przez historyczne deficyty mieszkaniowe prowadzą do indywidualnych programów mieszkaniowych, braku wymiany dobrych praktyk w sferze mieszkaniowej, a także zmniejszają, i tak już bardzo małą, skalę rozprzestrzeniania się innowacji w budownictwie mieszkaniowym w Polsce.

Konsekwencje takiego zindywidualizowania działań w sferze mieszkaniowej są również widoczne w polityce przestrzennej miast i gmin. Środowisko deweloperskie wskazuje, że w miastach brak jest terenów inwestycyjnych przeznaczonych w planach miejscowych na realizację budownictwa mieszkaniowego wielorodzinnego. Ten problem jest o wiele większy i dotyczy braku dla części obszarów miejskich miejscowych planów zagospodarowania terenu. Zamiast wprowadzać szybką ścieżkę przygotowania inwestycji mieszkaniowych, należy rekomendować, przy zasadniczym wsparciu władz centralnych, uchwalenie planów miejscowych w całej Polsce, uwalniać grunty pod zabudowę mieszkaniową w miastach i ograniczać możliwości realizacji inwestycji na „pustkowiach” poza miastem. Koszty takiej chaotycznej i żywiołowej suburbanizacji, jaka jest widoczna w Polsce, są ogromne. Należą do nich w szczególności: wzrost kosztów budowy i utrzymania infrastruktury m.in. wodno-kanalizacyjnej, energetycznej, komunikacji, funkcjonowania szkół podstawowych, w których uczą się dzieci spoza rejonu, zmniejszenie

25 A. Zubrzycka-Czarnecka, Social Actors... 
inwestycji w centrach miast, konflikty między ludnością miejscową i napływową na terenach wiejskich. Efektem rozlewania się miast jest też chaotyczna zabudowa terenów podmiejskich, a co za tym idzie - likwidacja naturalnych ekosystemów.

\section{Na własność czy wynajem?}

W odpowiedzi na pytanie o optymalną strukturę zasobu mieszkaniowego w Polsce na wstępie należy powrócić do różnic pomiędzy potrzebami mieszkaniowymi a oczekiwaniami mieszkaniowymi. W pracy Wealth and Freedom: An Introduction to Political Economy... D. Levine ${ }^{26}$ podkreśla, że oczekiwania mogą i powinny zostać spełnione z wykorzystaniem mechanizmów rynkowych, podczas gdy zaspokajanie podstawowych potrzeb mieszkaniowych powinno znajdować się w gestii państwa. Dlatego oczekiwania należałoby ściśle powiązać z możliwością wyboru, natomiast w sferze zaspokajania potrzeb mieszkaniowych mogłyby pojawić się pewne ograniczenia wyboru w zależności od zamożności poszczególnych gospodarek czy regionów²7.

Globalny kryzys finansowy z 2008 r. wywarł niezwykle silny wpływ na ocenę aktywności państwa w sferze mieszkaniowej. Społeczne budownictwo mieszkaniowe staje się ważną i coraz bardziej akceptowalną przez instytucje unijne częścią gospodarek europejskich. Silne w ostatnich dekadach powiązanie globalnego systemu finansowego z lokalnymi rynkami mieszkaniowymi spowodowało, że stabilność społeczna w poszczególnych państwach jest związana ze zrównoważonym rozwojem sfery mieszkaniowej, a im większy udział mieszkań użytkowanych jako własność w zasobie mieszkaniowym danego państwa, tym większa niestabilność sfery mieszkaniowej danej gospodarki ${ }^{28}$. Tę zależność może tłumaczyć niezwykle silny związek między sferą realną gospodarki a sferą finansową w XXI w. W badaniach międzynarodowych wskazuje się, że im bardziej rozwinięty system finansowy, tym większa jego siła oddziaływania. Tym samym znacząco się zwiększa wielkość finansowania w myśl zasady, że im wyższy poziom udzielonych kredytów mieszkaniowych w stosunku do PKB w danym państwie, tym wyższy udział osób mniej zamożnych w strukturze kredytowej ${ }^{29}$. Warunek jest jednak taki, że istnieją mechanizmy finansowania inwestycji mieszkaniowych bardziej zróżnicowane od prostego mechanizmu depozytowego, tj. oparte na listach zastawnych czy wspierające systematyczne oszczędzanie na mieszkanie. Kredyty hipoteczne o niskim oprocentowaniu, chociaż odbierane pozytywnie przez inwestorów i negatywnie przez wykluczonych z możliwości finansowania (osoby młode, por. Wymiar ilościowy sytuacji mieszkaniowej), skutecznie przyspieszają wzrost cen mieszkań. Tylko zwiększenie udziału mieszkań wynajmowanych na zasadach rynkowych w zasobie mieszkaniowym może przerwać ten niekorzystny trend wraz z wprowadzeniem większych restrykcji w finansowaniu inwestycji mieszkaniowych (nie na własne potrzeby mieszkaniowe)

26 D. Levine, Wealth and Freedom: An Introduction to Political Economy, Cambridge University Press, Cambridge 1995.

27 P. Lis, Polityka mieszkaniowa...

28 P. Lis, Cykle mieszkaniowe. Rola rynku i państwa, Wydawnictwo Uniwersytetu Ekonomicznego w Poznaniu, Poznań 2015.

29 Ibidem. 
tymczasowo tanim pieniądzem. Warunkiem jest zmiana struktury zasobu mieszkaniowego, a nie tylko nowych inwestycji mieszkaniowych.

Współczesne społeczeństwo powinno mieć do dyspozycji zasób mieszkaniowy na wynajem. W powiększeniu liczby tego typu lokali dużą rolę może odegrać partnerstwo publiczno-prywatne. Powodzenie tego rozwiązania zależy jednak od tego, w jaki sposób zabezpieczy się rynek przed selekcją negatywną, a zatem przed lokatorami, z którymi wiąże się duże ryzyko, co zwykle zdarza się przy tego typu przedsięwzięciach.

\section{Wszystkim czy wybranym?}

Odpowiedź na trzecie pytanie - czy wsparcie państwa kierować do szerokich grup społecznych, czy pomoc znacząco zawęzić - wydaje się prosta. Mianowicie w polityce mieszkaniowej powinny zostać przyznane wyraźne priorytety w zakresie wsparcia sfery mieszkaniowej przez państwo i władzę lokalną. Jedynie realizacja kolejnych priorytetów umożliwia rozszerzenie grona beneficjentów programów mieszkaniowych na kolejne grupy społeczne. Piramida priorytetów wygląda następująco: 1) osoby bezdomne, 2) osoby z orzeczoną przez sąd eksmisją, oczekujące na lokal socjalny, 3) osoby ubogie, w trudnej sytuacji mieszkaniowej, 4) grupy wrażliwe.

W odniesieniu do pierwszej grupy osób kluczowym wyzwaniem jest zmniejszanie zjawiska bezdomności długookresowej. Rozwiązaniem problemu nie są tylko działania na rzecz zapewnienia odpowiedniej liczby miejsc w noclegowniach i schroniskach dla bezdomnych. Programy skierowane do takich osób są bardzo skomplikowane i wymagają współdziałania na wielu płaszczyznach $^{30}$. Polityka mieszkaniowa nie może jednak, w opinii autora niniejszej pracy, przejść do realizacji kolejnych priorytetów bez rozwiązania problemów w podstawie wskazanej piramidy.

W przypadku osób z orzeczoną przez sąd eksmisją i oczekujących na lokal socjalny rząd powinien wesprzeć finansowo samorządy lokalne i jednocześnie tworzyć efektywne narzędzia do monitorowania mieszkańców gminnego zasobu mieszkaniowego oraz skutecznie usuwać te osoby, które same mogą zaspokoić swoje potrzeby mieszkaniowe. Odblokowanie kolejki oczekujących na lokale socjalne jest podstawowym warunkiem funkcjonowania masowego rynku najmu prywatnego.

Jeśli chodzi o pomoc osobom ubogim, to kluczowe rozwiązania dotyczą dwóch spraw: zasad wejścia do zasobu mieszkaniowego i wyjścia z niego, gdy gospodarstwo domowe przestaje spełniać kryteria uprawniające do zajęcia danego mieszkania, a także rodzaju działań na rzecz zmniejszania zaległości czynszowych. Należy przy tym podkreślić, że zasób społeczny nie może być eksploatowany przez lokatora przez całe jego życie, jeśli zajmie mieszkanie społeczne w wieku 20 lat (oczywiście inaczej jest w przypadku osób starszych). W zasobie społecznym niezbędne są wdrożenie i egzekucja zasad redukcji uciążliwego sąsiedztwa oraz zdecydowane i restrykcyjne działania wobec lokatorów o postawach aspołecznych. Konieczne jest zwiększenie efektywności przechodzenia z lokali socjalnych do lokali komunalnych, co daje lokatorom socjalnym

30 A. Szelągowska, Finansowanie społecznego budownictwa mieszkaniowego, CeDeWu, Warszawa 2011. 
możliwość awansu społecznego i wiąże się z podniesieniem standardu mieszkania ${ }^{31}$. Ważna jest pomoc osobom, które nie z własnej winy znajdują się w trudnej sytuacji mieszkaniowej i życiowej. Nie powinny być one deprecjonowane przez przydzielanie im mieszkań wyjątkowo substandardowych, gorszych niż inne lokale socjalne ${ }^{32}$. Konieczne jest podniesienie jakości lokalnej przestrzeni i usług publicznych, środowiska w najbliższym otoczeniu budynków mieszkalnych i budowanie wspólnotowości, tworzenie systemu angażującego lokatorów w sprawy dotyczące zamieszkiwanego przez nich zasobu. Niezwykle pilne stają się także działania podejmowane w celu zwiększenia jakości gminnych mieszkań, doprowadzenia lokali socjalnych i komunalnych do obowiązujących współcześnie norm.

Konieczne jest także wypracowanie kompleksowego podejścia do grup wrażliwych, a więc osób ze specjalnymi potrzebami, w szczególności: osób opuszczających domy dziecka, rodzinne domy dziecka i rodziny zastępcze, rodzin wielodzietnych, osób niepełnosprawnych, imigrantów, uchodźców i osób młodych wchodzących na rynek pracy. Ogromną rolę w tym obszarze odgrywa doświadczenie organizacji pozarządowych, które powinny zostać zaangażowane w te działania.

\section{Zakończenie}

W opracowaniu podjęto próbę odpowiedzi na trzy zasadnicze pytania formułowane w obszarze polityki mieszkaniowej: „Wspólnie czy indywidualnie?”, „Na własność czy wynajem?”, „Wszystkim czy wybranym?". Po pierwsze, prowadzenie polityki mieszkaniowej powinno być zróżnicowane w zależności od regionu, a zatem niezaspokojonych potrzeb mieszkaniowych społeczności lokalnych. Obecnie głównym celem polityki mieszkaniowej jest budowanie mieszkań, w mniejszym zaś stopniu - podnoszenie jakości istniejącego zasobu mieszkaniowego. W tym obszarze postuluje się wyznaczenie priorytetów na nowo, by było możliwe dostosowanie zadań i instrumentów polityki mieszkaniowej do zmian sytuacji mieszkaniowej Polek i Polaków. Po drugie, zrównoważony rozwój mieszkalnictwa wymaga istnienia znaczącego segmentu mieszkań przeznaczonych na wynajem w zasobie mieszkaniowym. Stąd państwo powinno tworzyć ramy instytucjonalne zapewniające rozwój tego segmentu, a samorządy lokalne powinny realizować programy mieszkaniowe, które staną się impulsem do dalszego rozwoju rynku lokali mieszkaniowych. Po trzecie, w polityce mieszkaniowej powinny zostać przyznane wyraźne priorytety w zakresie wsparcia sfery mieszkaniowej przez państwo i władze lokalne. Realizacja kolejnych priorytetów umożliwia bowiem rozszerzenie grona beneficjentów programów mieszkaniowych o kolejne grupy społeczne.

31 Z. Rataj, Społeczne budownictwo mieszkaniowe i jego rola w zaspokajaniu potrzeb mieszkaniowych niezamożnych gospodarstw domowych w Polsce, CeDeWu, Warszawa 2018.

32 A. Przymeński, M. Oliwa-Ciesielska, Publiczna pomoc mieszkaniowa a demarginalizacja społecznej ludności ubogiej, Wydawnictwo Uniwersytetu Ekonomicznego w Poznaniu, Poznań 2014. 


\section{Bibliografia}

Andrzejewski A., Polityka mieszkaniowa, wyd. 3 zmien., Państwowe Wydawnictwo Ekonomiczne, Warszawa 1987. Bryx M., Rudzka I., Alternatywny model kredytowania hipotecznego na cele mieszkaniowe, Warszawski Instytut Bankowości, Warszawa 2020.

Bryx M., Rudzka I., Łobejko S., Dostępność mieszkań na własność i wynajem w Polsce - I pótrocze 2020 r., Warszawski Instytut Bankowości, Warszawa 2021.

Jarecki P., Kucharska-Stasiak E., Miklaszewska A., Olbińska K., Wieteska-Rosiak B., Załęczna M., Optymalne programy wsparcia budownictwa mieszkaniowego - analiza efektywności, Warszawski Instytut Bankowości, Łódź 2020

Levine D., Wealth and Freedom: An Introduction to Political Economy, Cambridge University Press, Cambridge 1995.

Lis P., Cele i instrumenty społecznej polityki mieszkaniowej [w:] Współczesne przemiany środowiska mieszkaniowego - wybrane problemy, red. J. Dzieciuchowicz, Wydawnictwo Uniwersytetu Łódzkiego, Łódź 2011.

Lis P., Cykle mieszkaniowe. Rola rynku i państwa, Wydawnictwo Uniwersytetu Ekonomicznego w Poznaniu, Poznań 2015.

Lis P., Polityka mieszkaniowa dla Polski. Dlaczego potrzeba więcej mieszkań na wynajem i czy powinno je budować państwo?, Forum Idei, Fundacja im. Stefana Batorego, Warszawa 2019.

Lis P., Polityka państwa w zakresie finansowania inwestycji mieszkaniowych, C.H. Beck, Warszawa 2008.

Lis P., Rataj Z., Suszyńska K., Limitations in the Diffusion of Collaborative Housing. Evidence from Poland (praca nieopublikowana).

Przymeński A., Oliwa-Ciesielska M., Publiczna pomoc mieszkaniowa a demarginalizacja społecznej ludności ubogiej, Wydawnictwo Uniwersytetu Ekonomicznego w Poznaniu, Poznań 2014.

Rataj Z., Społeczne budownictwo mieszkaniowe i jego rola w zaspokajaniu potrzeb mieszkaniowych niezamożnych gospodarstw domowych w Polsce, CeDeWu, Warszawa 2018.

Szelągowska A., Finansowanie społecznego budownictwa mieszkaniowego, CeDeWu, Warszawa 2011.

Zubrzycka-Czarnecka A., Polityka miejska wobec starzenia się populacji miast - na przykładzie Polski, Francji i Kanady, „Problemy Polityki Społecznej. Studia i Dyskusje” 2012, nr 18, s. 119-128.

Zubrzycka-Czarnecka A., Polityka mieszkaniowa we Francji na przełomie XX i XXI wieku, Aspra, Warszawa 2011.

Zubrzycka-Czarnecka A., Social Actors in the Housing Policy process. A Constructivist Perspective, Elipsa, Warszawa 2019.

\section{Raporty i dokumenty}

Eurostat, Distribution of Population by Tenure Status, Type of Household and Income Group - EU-SILC survey (ilc_ Ivho02).

Eurostat, House price index - quarterly date [PRC_HPI_Q], https://appsso.eurostat.ec.europa.eu/nui/show. do?dataset=prc_hpi_q\&lang=en.

Główny Urząd Statystyczny, Budownictwo mieszkaniowe w okresie I-X 2020 r., Warszawa 2020.

Główny Urząd Statystyczny, Gospodarka mieszkaniowa i infrastruktura komunalna w 2019 r., Warszawa 2020.

Główny Urząd Statystyczny, Gospodarka mieszkaniowa w latach 2013-2017, Warszawa-Lublin 2018.

Główny Urząd Statystyczny, Ludność. Stan i struktura oraz ruch naturalny w przekroju terytorialnym w 2020 r. (stan w dniu 3 XII), Warszawa 2021.

Główny Urząd Statystyczny, Obrót nieruchomościami w 2014 r., Warszawa 2015. 
Główny Urząd Statystyczny, Obrót nieruchomościami w 2015 r., Warszawa 2016. Główny Urząd Statystyczny, Obrót nieruchomościami w 2016 r., Warszawa 2017.

Główny Urząd Statystyczny, Obrót nieruchomościami w 2017 r., Warszawa 2018.

Główny Urząd Statystyczny, Obrót nieruchomościami w 2018 r., Warszawa 2019.

Główny Urząd Statystyczny, Obrót nieruchomościami w 2019 r., Warszawa 2020.

Główny Urząd Statystyczny, Rocznik Statystyczny Warszawy 2020, Warszawa 2020.

Główny Urząd Statystyczny, Sytuacja demograficzna Polski do 2019 r. Migracje zagraniczne ludności w latach 2000-2019, Warszawa 2020.

Narodowy Bank Polski, Raport o sytuacji na rynku nieruchomości mieszkaniowych i komercyjnych w Polsce w 2019 r., Departament Stabilności Finansowej NBP, Warszawa 2020.

Narodowy Bank Polski, Informacja o cenach mieszkań i sytuacji na rynku nieruchomości mieszkaniowych i komercyjnych w Polsce w III kwartale 2020 r., Warszawa 2020.

Narodowy Bank Polski, Informacja o cenach mieszkań i sytuacji na rynku nieruchomości mieszkaniowych i komercyjnych w Polsce w II kwartale 2020 r., Warszawa 2020. 